\title{
RELATIONSHIP NETWORK CHARACTERISTICS OF SPORTS AND NON- SPORTS YOUNG ADOLESCENTS
}

\author{
Péterné Blatt \\ University of Pécs - Faculty of Humanities and Social Sciences, Pécs, Hungary
}

\begin{abstract}
From school onwards, children spend more and more time with their peers without direct adult supervision. In peer groups, the emphasis is on shared interests, understanding and trust, rather than joint activities. The biological changes associated with adolescent sexual maturation also lead to changes in social relationships. The topic is particularly topical now, in the wake of the COVID-19 pandemic, when opportunities for face-to- face communication have been significantly reduced, leading in many cases to a transformation of relationships.
\end{abstract}

Playing sport expands the individual's range of experience: he or she is exposed to a new social environment, has the opportunity to form new relationships, and encounters a new set of values and norms. All this shapes their personality, their individuality and has an impact on their whole life. However, many children today do not play sport regularly, partly because of the increased mental workload and demands and the resulting lack of time. In my research, I was looking for answers to the question of how regular sporting activities affect the social relationships of young adolescents. As the data from my research show, regular sporting activity has a beneficial effect on both the extension and the intensity of children's relational networks, especially for those playing team sports. Keywords: network, friends, social capital, sport, inactive lifestyle

\section{THEORETICAL BACKGROUND}

\section{DEFINING THE CONCEPT OF A NETWORK OF RELATIONSHIPS}

"A network is nothing but a set of actors (ego(s), alter(s)) and the ties between them (HUSZTI, 2015a)." The size of the network of relationships provides information about the social capital of the individual. The concept was first defined in the 1980s by Bourdieu and later by Coleman. Thanks to the latter's work, social capital has become an independent social science theory.

Bourdieu uses the term social capital to refer to interpersonal relationships based on sympathy and without calculation (PUSZTAI, 2015). "...the amount of social capital possessed by an individual depends on the extent of the network of relations that he can actually mobilize, on the one hand, and on the amount of capital (economic, cultural or symbolic) possessed by those with whom he is in contact, on the other (BOURDIEU, 1983: 168)." According to Coleman's definition, this type of capital 'is reproduced by living relations, based on shared norms, mutual trust, mutual exchange ... it is the type of capital that is most easily transformed into human capital and is able to make up for other capital deficits (PUSZTAI, 2015)."

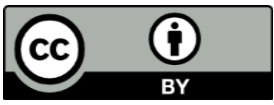


Social relationships are a very important part of an individual's life. They are beneficial for mental health and subjective well-being, but they are also essential for social integration and everyday well-being. A well-functioning network of relationships can therefore be said to be both a source of well-being and also linked to well-being (VASTAG - HUSZÁR, 2008). The richest source of capital in the formal and informal structures of relationship formation is the cohesion of the network of relationships, when one's friends are also connected to each other. In this structure, everything that cannot be acquired individually becomes available to the individual, but if the individual leaves the structure, he or she can harm him or herself and others (PUSZTAI, 2015).

People who have many, strong ties, i.e. a dense but homogeneous network of relationships, are more at risk of isolation than those who have several weak ties. Their network of connections allows information to flow more widely, so they have easier access to different resources and are better able to integrate into society (HUSZTI, 2015b). At the same time, Coleman argues that it is the closed form of network based on strong ties (closure) that is most advantageous for the production of social capital (PUSZTAI, 2015).

A crucial question is who is considered a member of the network of contacts. Laumann, Mardsen and Prensky distinguish between two approaches:

- realistic: Those who belong to a network are those who are perceived as belonging to the network and who themselves consider themselves to be members of it.

- nominalist: the researcher's theoretical interests determine who is part of the network

(LAUMANN et al, 1989, cited in HUSZTI, 2015a).

\section{GROUPING OF CONTACT NETWORKS}

We can distinguish between complete and individual networks of relationships. When exploring the whole network, we look at all members of that network, so each person is reporting facts about everyone else. When examining the individual network of relationships, the network is explored from the perspective of the individual, who is the source of the information.

Wassermann and Faust typified networks of relationships using a different approach. They distinguished four types of networks based on the properties of the links between the individuals that make up the network:

- one-dimensional network: the relationships between pairs form the basis, and the analysis includes the characteristics of the actuators.

- two-dimensional network: examines pairs where the two members belong to different networks. It focuses on the relationships between them or on a network of individuals and events. 
- special diadic network: it takes into account only one type of relationship of a given person (e.g. mother-child).

- egocentric network: the focus of the study is on an individual and the people associated with him or her. This type of measurement is also often used to study peer support

(WASSERMAN - FAUST, 1994, cited in HUSZTI, 2015a).

Anna Rácz (2014), quoting Granovetter, distinguishes between strong and weak relationships. A strong relationship is one with those persons with whom one meets frequently, to whom one is emotionally attached and on whom one can always rely. Weak relationships are not part of the ego's narrow social circle, but are still useful. They are the bridge between the subject's narrow circle and other groups in society. "Putnam distinguishes between bonding and bridging relationships in his studies of relationship networks. The former provides the cohesion of smaller communities, the latter refers to the formation of comprehensive bonds between networks (PUSZTAI, 2015)."

\section{METHODOLOGICAL CONSIDERATIONS}

Sport is influenced by a number of factors. These include the individual's psychological and biological characteristics, attitudes towards sport, place of residence, economic circumstances and social status (FÖLDESINÉ et al., 2010). Cvetkovic et al. (2014) also found that children in rural areas participate less in sports than children in urban areas, as they have fewer opportunities to do so. In contrast to education, there is also a problem with access to sport: in some types of settlements and regions, there is no wide choice of sports, or even the possibility to play sports at all (BODNÁR, 2015)." Balogh (2015) concludes from her research that the age of 13-14 years is a dividing line in terms of psychosocial development. Indeed, the level of physical activity starts to decline steadily from this age. At the same time, the importance of peer networks of mutual support peaks in adolescence (HEIM - BRETTSCHNEIDER, 2002).

On the basis of these considerations, my sample of the population included only 6th-7th graders from Pécs, thus excluding interpretation bias due to the sporting opportunities of different municipalities.

I used a non-probability, partly theoretical and partly access sampling procedure (SZOKOLSZKY, 2004). I have tried to work with a sample that meets the validity criteria, and therefore I have tried to achieve diversity in the five schools (suburban, inner- city, church and state schools are all included in the study - access sample).

In my research I formulated two hypotheses.

H1: Children who are active in sport have more extensive social relationships than their non-active counterparts.

H2: Children who are active in sport also have more intense social relationships than children who are not. 
I conducted my research using a quantitative research method, including a standard questionnaire survey. I used a questionnaire of my own design, with questions focusing on the issues outlined above. Responses were voluntary and anonymous.

Most of the answers to the questions in my cross-sectional survey were processed using the statistical software SPSS 26 . In all cases, $\mathrm{p}<0.05$ was considered significant for the interpretation of the data obtained. Data were processed and presented in percentage form. Three questions asked respondents to indicate the number of friends they had. These questions were processed using the average calculation method.

When interpreting the data, it is important to bear in mind that the study was conducted during the second wave of the COVID 19 outbreak.

\section{RESULTS}

With the first two questions, and by providing gender and age, I wanted to map the basic data of the study sample. In total, 245 students returned a questionnaire to be evaluated. The average age of the respondents was 12.63 years, and their social and gender composition and their relationship with sports participation are shown in the Table 1.

Table 1: Composition of the study sample (persons) $N=245$

\begin{tabular}{|c|c|c|c|}
\hline \multicolumn{2}{|c|}{ athlete } & \multicolumn{2}{c|}{ non-athlete } \\
\hline \multicolumn{2}{|c|}{147} & \multicolumn{2}{c|}{98} \\
\hline boy & girl & boy & girl \\
\hline 96 & 51 & 68 & 30 \\
\hline
\end{tabular}

(own editing)

The first question asked which pupils were active in sport. The Table 2 shows the distribution of activity by gender.

Table 2: Distribution of study sample by active

\begin{tabular}{|c|c|c|}
\cline { 2 - 3 } \multicolumn{1}{c|}{} & \multicolumn{2}{c|}{ activity } \\
\hline genus & athlete & non-athlete \\
\hline boy & $58,53 \%$ & $41,47 \%$ \\
\hline girl & $62,96 \%$ & $37,04 \%$ \\
\hline
\end{tabular}

Pearson Chi-Square: 0,417

(own editing)

The results of the Chi-square test also confirm that no significant difference in the sex distribution is found.

The second question in the basic questions was about the sport. For both girls and boys, I came across a very wide repertoire of different sports. The Table 3 also shows that gender resulted in a significant difference in terms of sport. We can clearly see that girls prefer individual sports. 
Vol 4, No 2 (2021): Stadium -Hungarian Journal of Sport Sciences https://doi.org/10.36439/shjs/2021/2/10563

Table 3: Distribution of study sample by sport and gender $N=147$

\begin{tabular}{|c|c|c|}
\hline & \multicolumn{2}{|c|}{ sport } \\
\hline genus & individual sport & team sport \\
\hline boy & $47,36 \%$ & $52,64 \%$ \\
\hline girl & $66,66 \%$ & $33,34 \%$ \\
\hline
\end{tabular}

Pearson Chi-Square: 0.009

(own editing)

The questions of the questionnaire focused on friendships, and through them on the intensity and extensiveness of the respondents' network of relationships. By intensity of the network I mean the depth and frequency of contact, and by extensiveness I mean the extent of contact (number of friends).

With the first set of questions, I tried to define the extent of time spent with friends. For both questions, respondents were given a choice of four possible time intervals. The third question was for weekdays and the fourth for weekends.

There were no significant differences in the cross-tabulation of time spent with friends during the week by gender and sport activity, but there were significant differences by type of sport (0.02).

As shown in Figure 1 students who play team sports spend significantly more time with their friends.

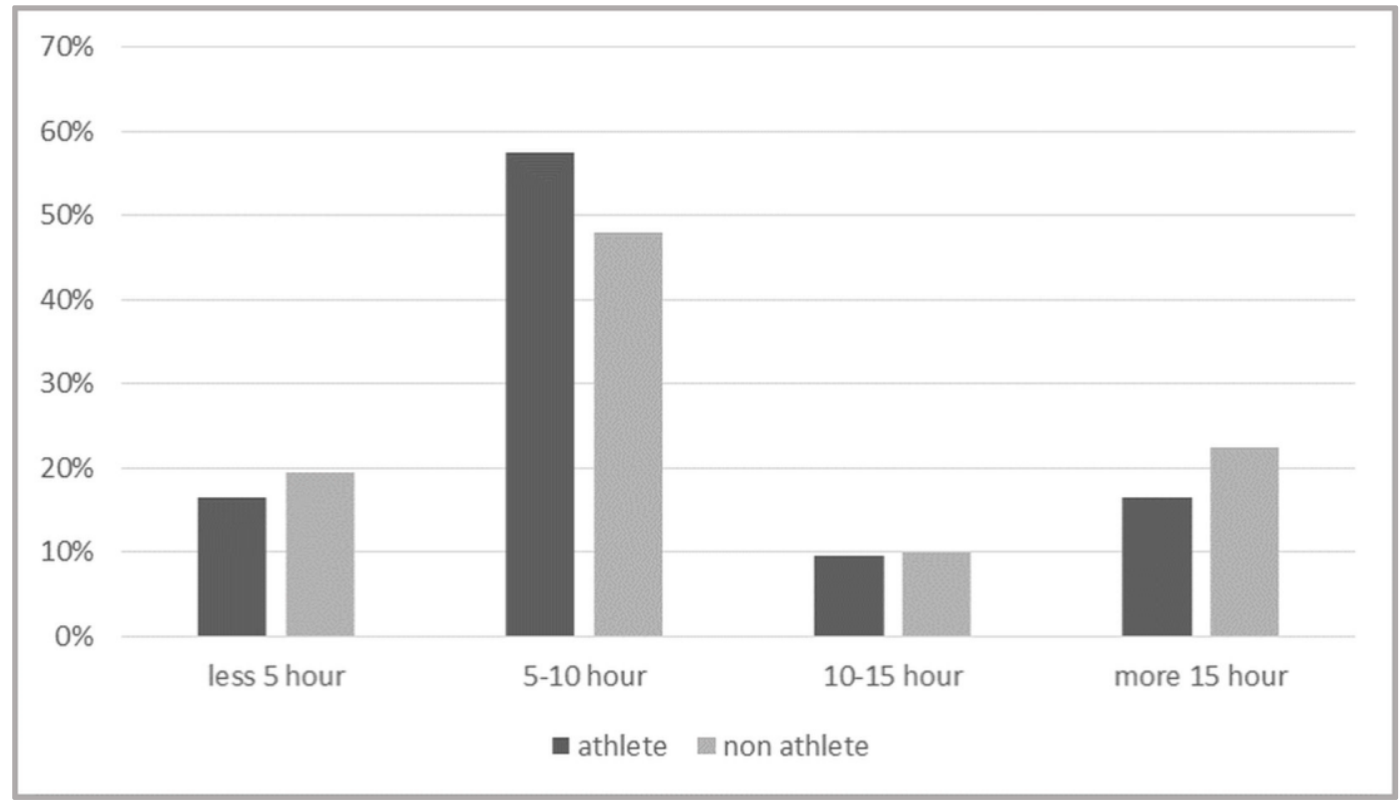

Figure 1: Time spent with friends by sport $N=147$

(own graph)

The next question also focused on the amount of time spent with friends, but this time 
at the weekend. Students who play sports, especially team sports, often spend weekends at league matches. Besides regular sporting activities and studying, they have less time for friends, unless they are fellow sportspeople.

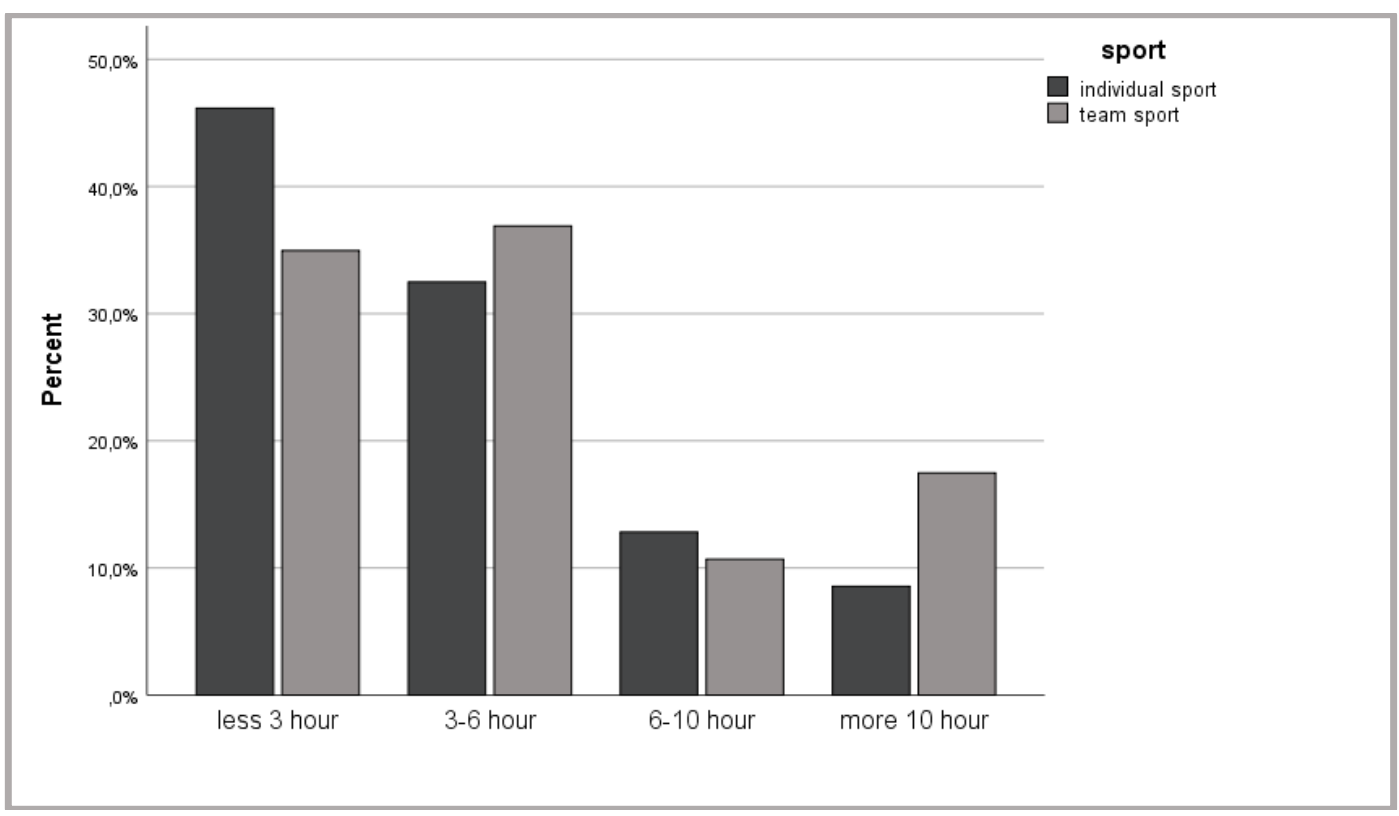

Figure 2: Weekend leisure time with friends by sport $N=147$ (own graph)

In my study sample, I did not get significant differences in any of the cases (gender, activity, sport). Despite this, I think it is worth taking a look at the breakdown by sport, shown in Figure 2. The graph clearly shows that in the largest interval there are twice as many team sports players as individual sportsmen and women, of whom almost half spend less than 3 hours with their friends. I think these results support the more intensive socialization effect of team sports.

In the next section of three questions, I did not give a choice, the respondents had to answer the questions. In the fifth question, I wanted to find out the number of friends in the communities that are part of their daily lives. In addition to the options I gave, students were also given the option of indicating the number of other friends they had in areas that were important to them. The data show average values. 


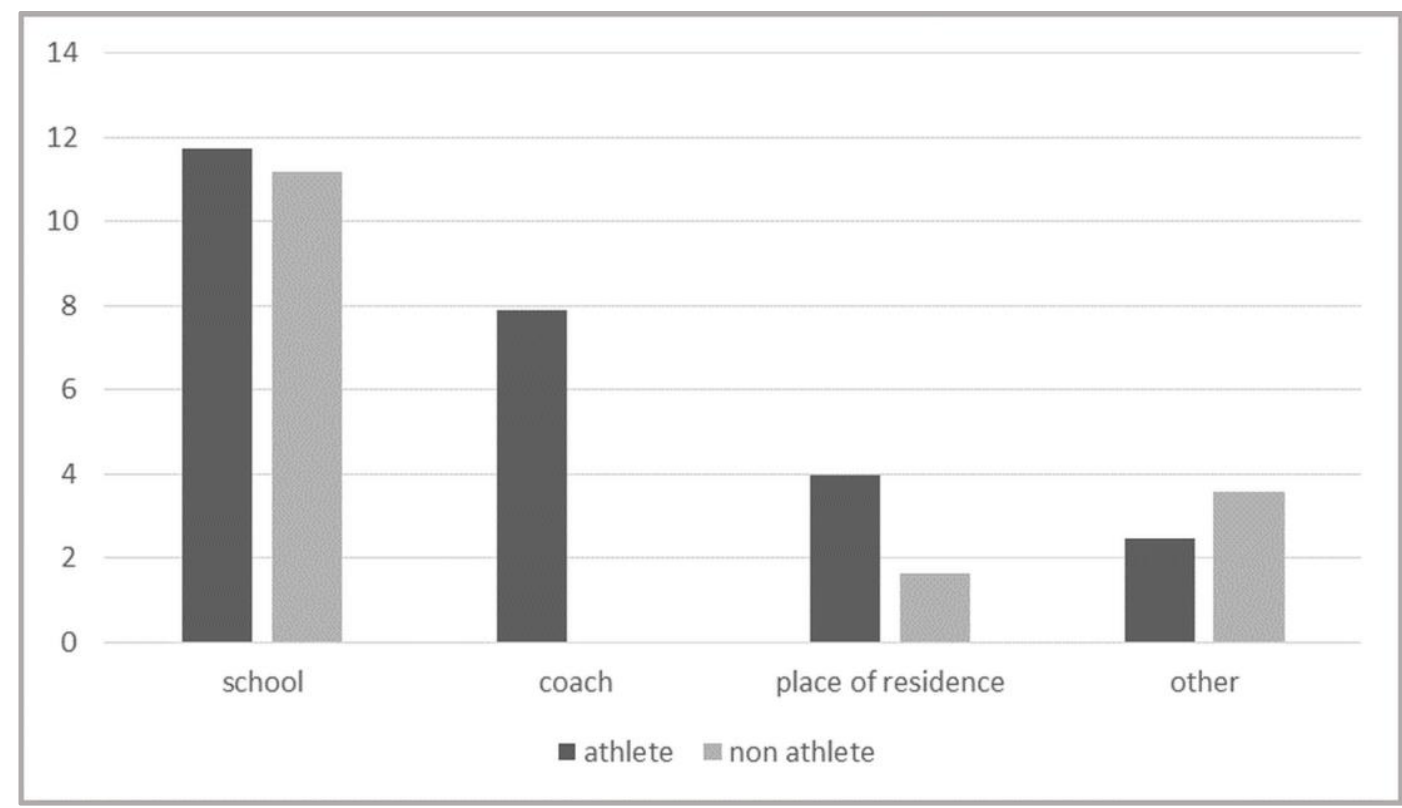

Figure 3: Average number of friends per person $N=245$

(own graph)

As can be clearly seen in chart 3, regardless of activity, the school was the place where most of the respondents had friends, followed by coaches for athletes. This category is of course zero for non-athletes. It can be clearly seen that athletes have more friends than their non-athlete counterparts in all areas except for the other group. For this category, I also asked for an explanation of what exactly the respondents mean by this. Some reported friends in the neighborhood of close relatives (grandparents, cousins), but for a significant proportion of students the answer was the internet, virtual space. The difference in the number of friends between students who exercise regularly and students who do not exercise is not significant when school, place of residence and other categories are taken into account. However, it should be borne in mind that there is another socialization medium in the lives of children who participate in sport, through sport, which can further enrich their friendships. In their case, we must also take into account the friends among their training partners when aggregating the data, and thus obtain a significant difference in their favor.

After mapping the number of friends, I focused my attention on the intensity of the relationships, in addition to their intensity. In the next two questions, students were still asked to provide figures, this time on how many people they would invite to their birthday party and how many people they could count on for help if they got into trouble. The questions were intended to gauge the number of friends who make up the narrow core of the circle of friends just given. 
Vol 4, No 2 (2021): Stadium -Hungarian Journal of Sport Sciences

https://doi.org/10.36439/shjs/2021/2/10563

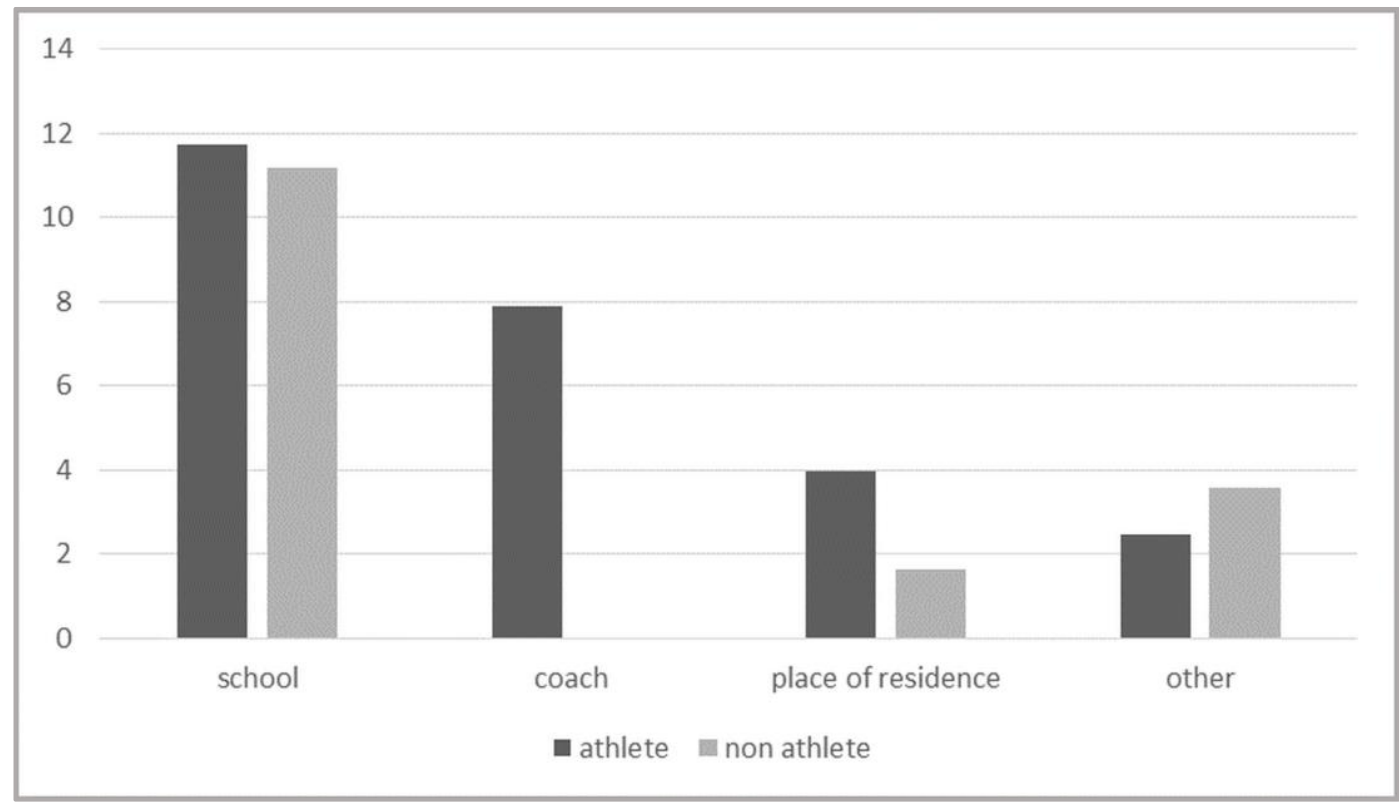

Figure 4: Average number of friends invited to a birthday party, in head count $N=245$ (own graph)

The number of friends invited to the birthday party was similar to the total number of friends (Figure 4). Everyone from school would invite the most people, followed by coaching colleagues also coming in second place for athletes. No significant difference is seen for the residence category, but again for non-athletes there is a spike in the other groups detailed earlier.

The final question with figures was for the number of trusted friends that respondents could count on if they got into trouble. The dominance of schoolmates is still the case, and there is no change in the order of the other categories. The difference between athletes and non-athletes is clearly visible (Figure 5).

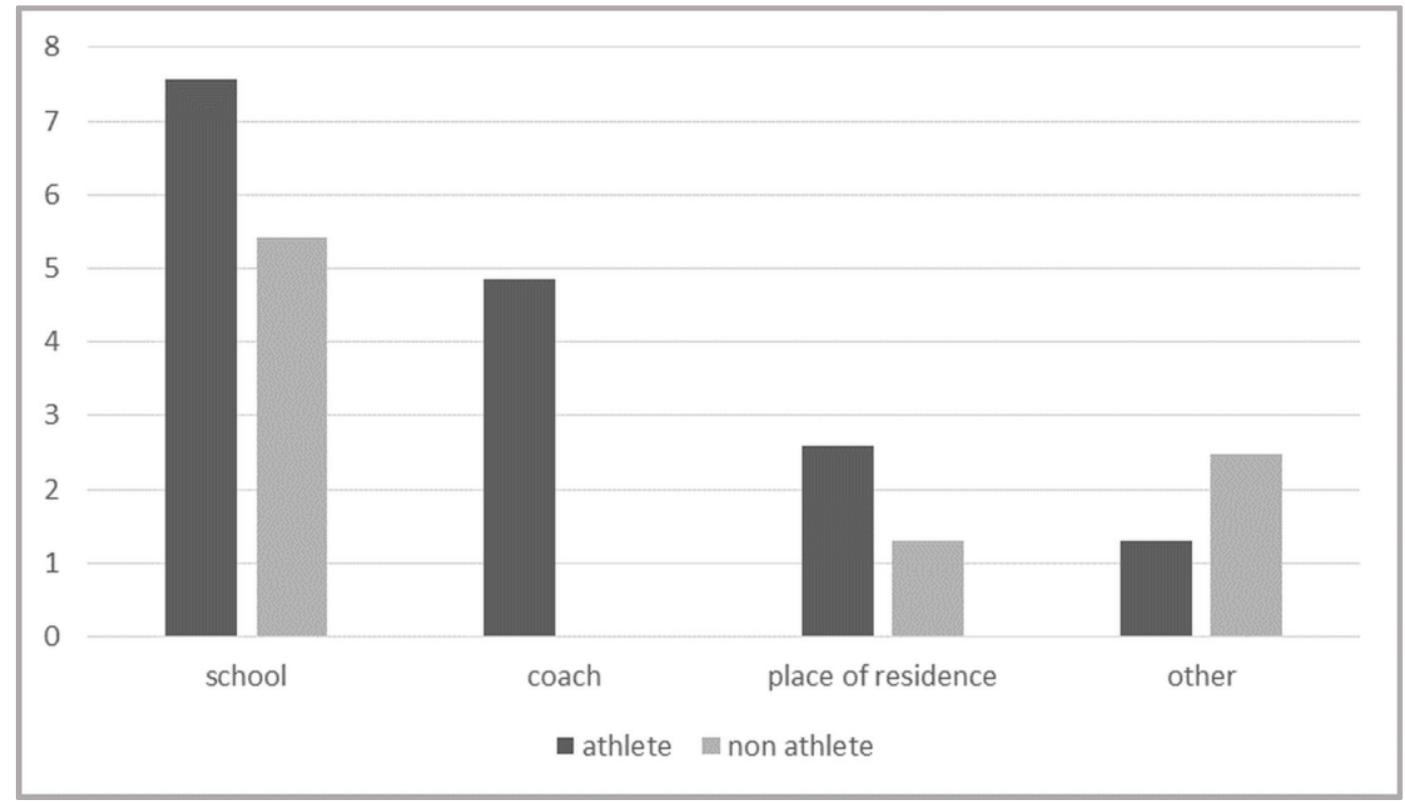

Figure 5: Average number of friends in trouble, per person $N=245$ 


\section{(own graph)}

Overall, the figures show that children who play sport have more friends than their nonathlete peers, even if you exclude coaching partners. This difference was found for all three questions.

The next two questions were specifically designed to explore the depth of the friendship. The eighth question asked how many friends the respondents had with whom they could share their secrets (Figure 6). I think people don't trust just anybody with their secrets, only those they trust and not just superficially.

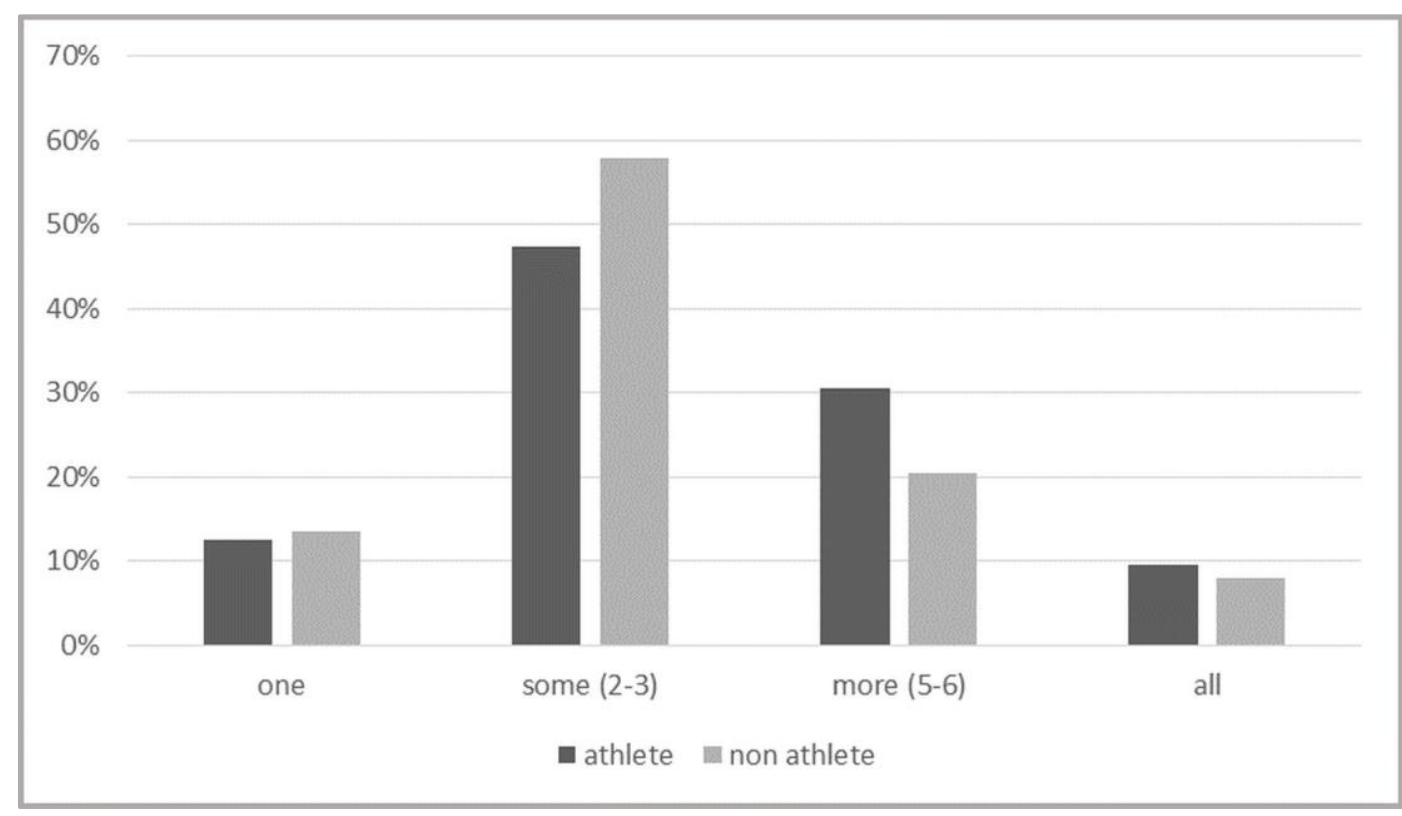

Figure 6: Number of friends respondents would trust with their secrets $N=245$

(own graph)

It is clear that there is no significant difference in terms of sporting activity, but a much higher number of students who played sport chose more than one category. I was curious to see if I could find a difference in favor of team sports, as students have a much better chance of making friends in a team than in individual sports. I therefore crosschecked the data with the sport responses and found a significant difference of 0.000 . The significant difference between the two variables is illustrated in Figure 7. More than half of the individual sportsmen and sportswomen feel really close to only a few friends, and $20 \%$ only one. By contrast, the proportion of team sportsmen and women in this category is half as high, but more than twice as high for those with five to six close friends. The ratio of those with more or less than three deep friendships is half to half, while for individual athletes the ratio is $4: 1$. 
Vol 4, No 2 (2021): Stadium -Hungarian Journal of Sport Sciences https://doi.org/10.36439/shjs/2021/2/10563

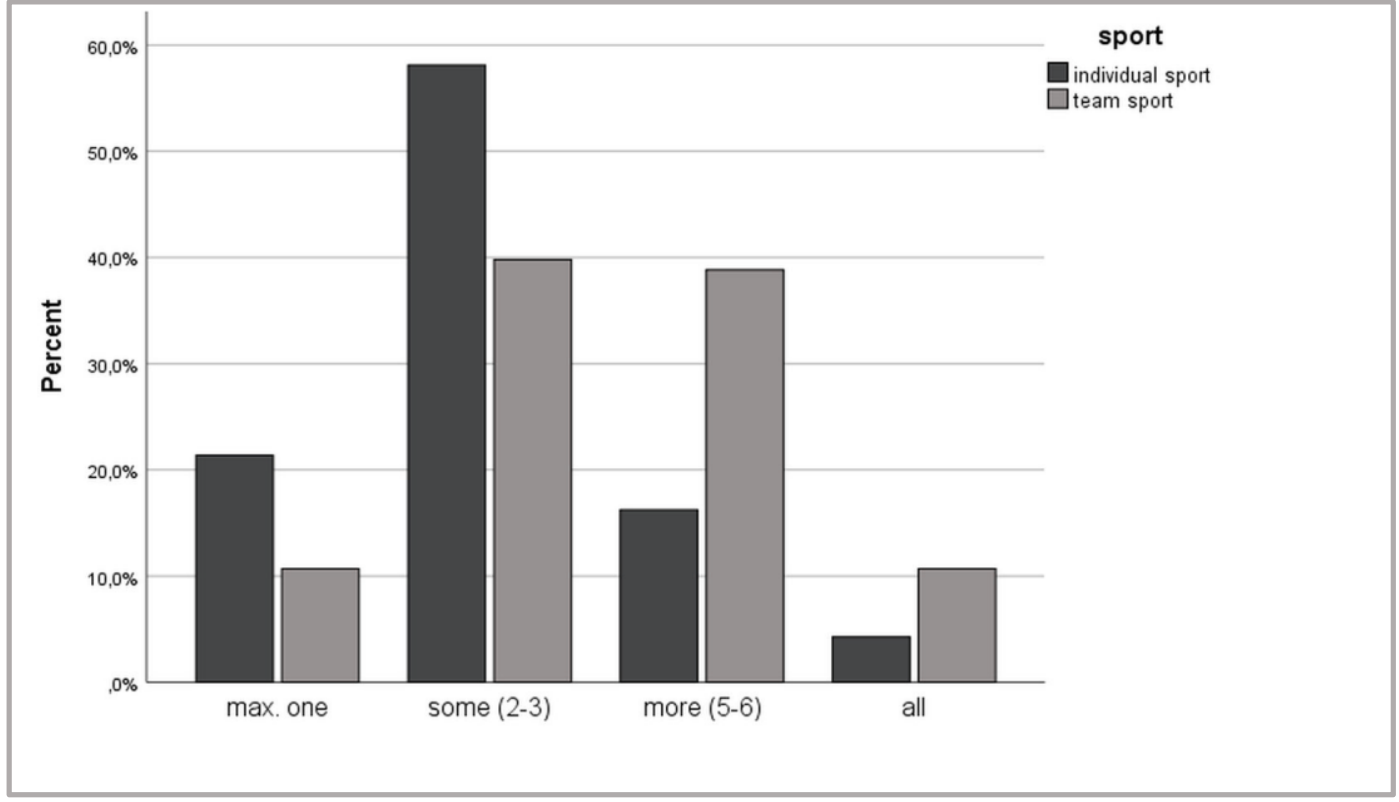

Figure 7: Sharing secrets between team and individual athletes $N=147$ (own graph)

Following on from the previous question, I then looked at the issue of loneliness. The question asked how often the respondents felt lonely (Figure 8).

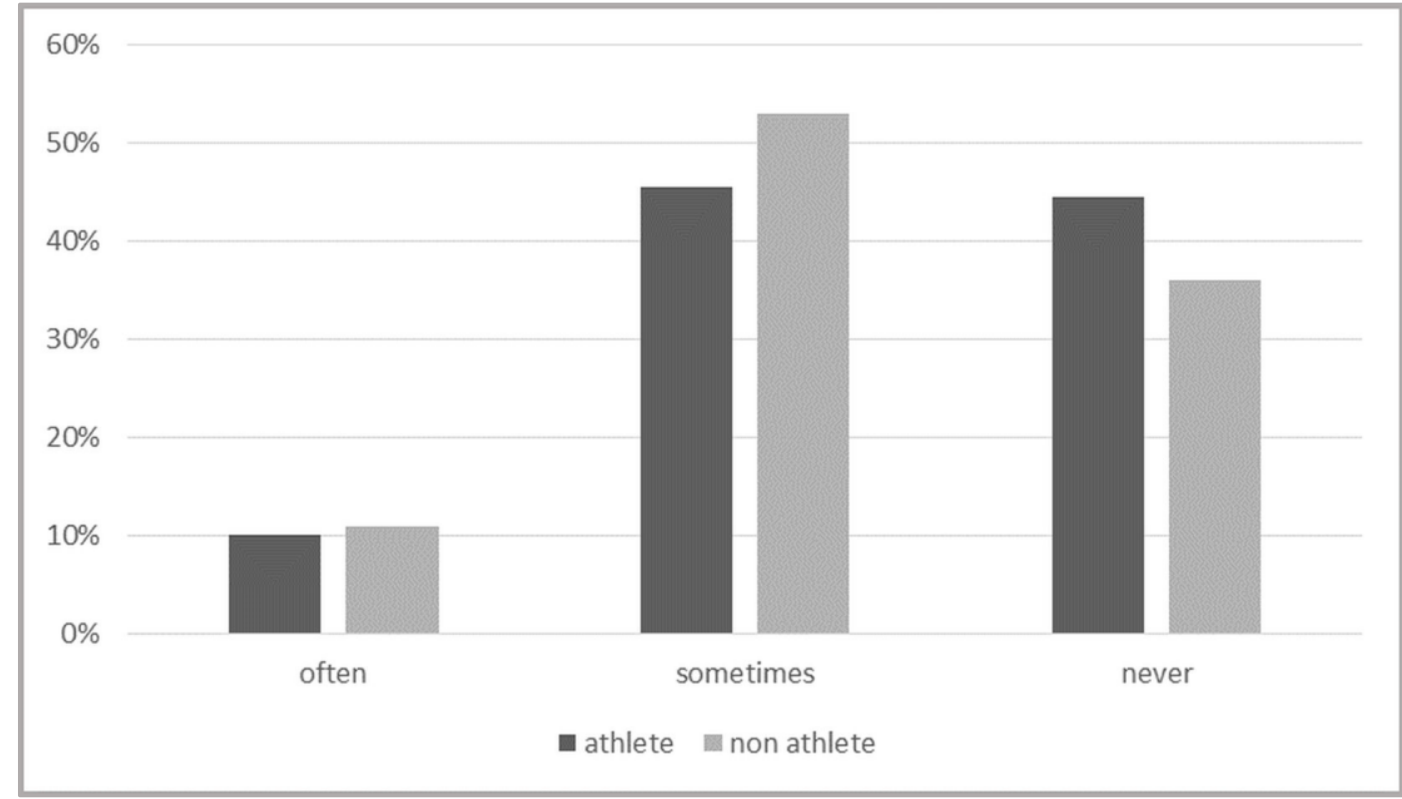

Figure 8: Frequency of feeling lonely $N=245$

(own graph)

Again, I looked at the results by sport and by gender, and I found a significant difference in both cases, with a difference of 0.016 for sport and 0.001 for gender (Figure 9-10). 
Vol 4, No 2 (2021): Stadium -Hungarian Journal of Sport Sciences

https://doi.org/10.36439/shjs/2021/2/10563

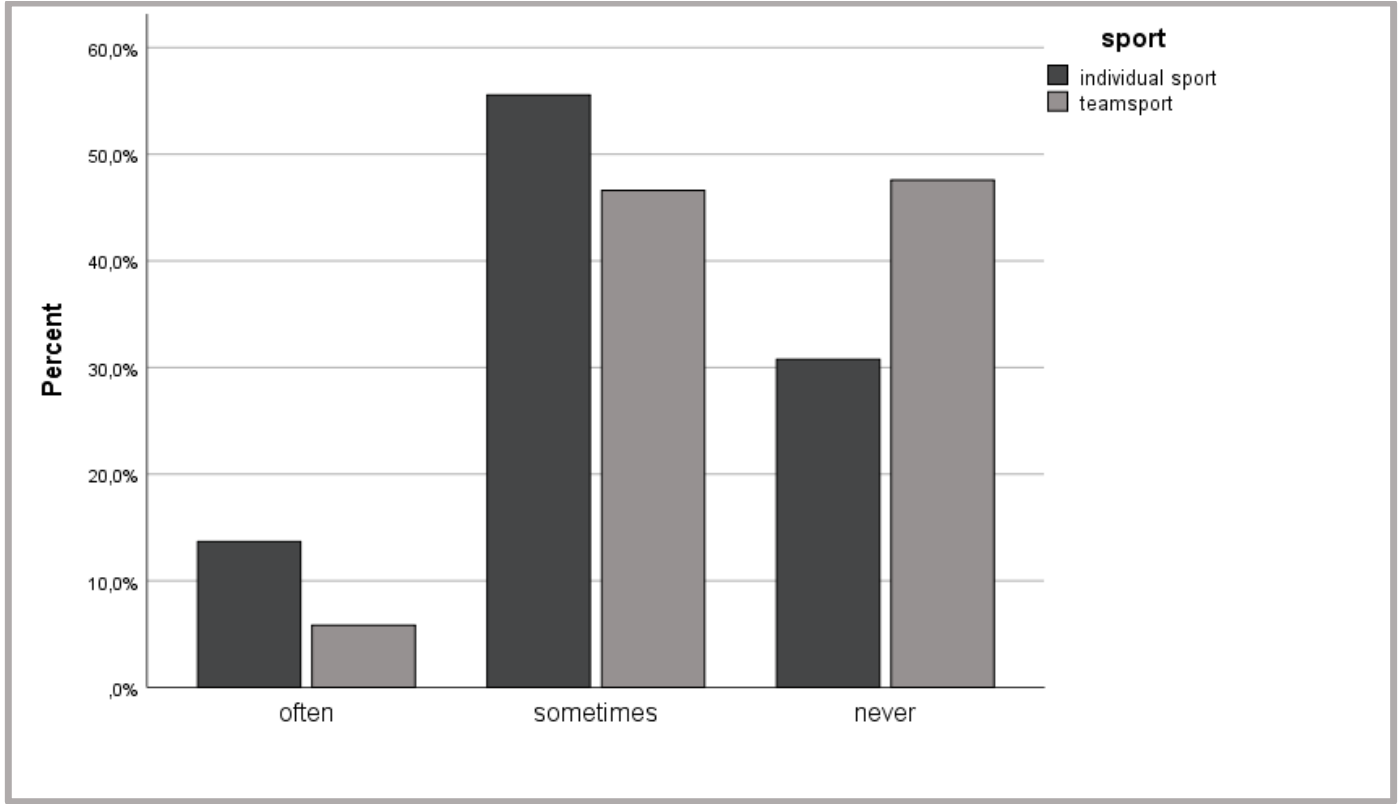

Figure 9: Feelings of loneliness among team and individual sports N=147 (own graph)

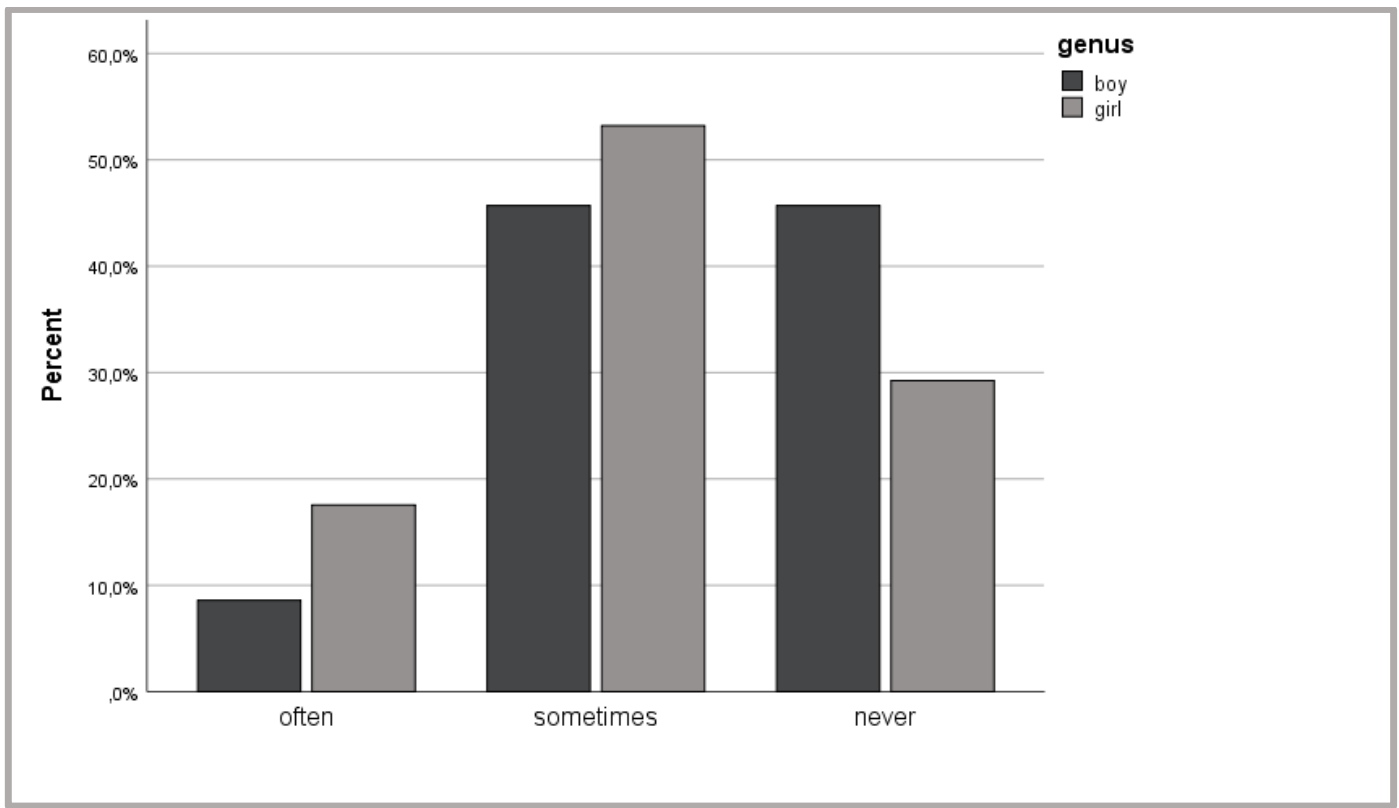

Figure 10: Feelings of loneliness by gender $N=245$ (own graph)

It can be seen that there are twice as many girls who are often lonely as boys, and nearly $20 \%$ fewer girls who are never lonely. The figures are similar across sports. A much higher number of team sports respondents say they are never lonely, and only a few $\%$ say they often feel lonely. 


\section{DISCUSSION}

\section{REVIEW OF THE HYPOTHESES}

H1: Children who are active in sport have more extensive social relationships than their non-active counterparts.

Confirmed.

When the data were aggregated, it was clear that children who play sport have more friends than their non-athlete peers, even when coaching partners are excluded. This difference was reported for all three questions.

H2: Children who are active in sport also have more intense social relationships than children who are not.

Confirmed.

The depth of relationships was indicated by the questions that referred to the number of trusted friends, i.e. those they could rely on in times of trouble or to whom they could entrust their secrets. The data showed a predominance of athletes for both questions.

\section{SUMMARY}

The aim of my research was to understand the relationship networks of sport and nonathlete students and their characteristics.

The amount of time spent with friends during the week and at weekend for athletes suggests that they are often with their friends during training.

Looking at the number of friends, I also got very positive data. In all cases, athletes reported more friends than non-athletes. This shows that they are more popular at school and in their home town. The highest number of friends for all is at school, followed by sportsmen and sportswomen among their coaching colleagues, at home and finally in other places. In the other category, the internet and the virtual world accounted for a large part, often in very large numbers. The low number of friends at home and the increasing number of online friends is certainly a cause for reflection. The ranking of these categories also reflects the time spent in school, where children spend most of their time and are most likely to make friends. Of course, this depends to a large extent on the personality of the student.

In terms of the depth of friendships, I concluded that athletes have more trusted friends, with team sports being the most prominent.

When examining feelings of loneliness, no significant differences were found between students who played sports and students who did not, but significant differences were found for sport and gender. Students playing individual sports were twice as likely to 
report feeling lonely as their team sports peers. The same difference was found when analysing the data by gender, with boys half as likely to feellonely.

Overall, it can be said that regular sporting activity has a positive impact on children's social networks, as they have wider and deeper connections. Sports clubs provide an additional socialization medium for pupils. Through training, children meet new people and have the opportunity to make friends not only in the school or home environment, which is an integral part of their daily lives. Among sports, team sports offer even greater potential. This is why, in addition to the many positive effects of sport, it is important to encourage children to take up physical activity from an early age.

However, when looking at the results, we should also not lose sight of the fact that there is no clear explanation for the differences between athletes and non-athletes. It is far from certain that someone makes more friends because they play sport. It is possible that they joined a sports club because they already had friends there. It is also important to bear in mind that the sample was drawn specifically from students in Pécs, so it is by no means representative at national level. When interpreting the data, it is also important to bear in mind that they reflect a current situation between the first and second wave of the pandemic. However, they can therefore provide an excellent basis for comparison for a subsequent study on a similar topic in the post- pandemic period.

\section{REFERENCES}

Balogh, L. (2015). A fiatalok fizikai aktivitását és az ülő életmódjából eredő mozgásszegény életvitelét meghatározó főbb társadalmi és környezeti tényezők. In Révész, L. \& Csányi, T. (Eds.): Tudományos alapok a testnevelés tanításához. I, Budapest: Magyar Diáksport Szövetség, 200-224.

Bodnár, I. (2015). Egyenlőség - egyenlőtlenség - esélyegyenlőség a sportban. In Laczkó, T. \& Rétsági, E. (Eds.): A sport társadalmi aspektusai, Pécs: Pécsi Tudományegyetem Egészségtudományi Kar, 109-137.

Bourdieu, P. (1983). Gazdasági tőke, kulturális tőke, társadalmi tőke. In Angelusz, R. (1999, Eds.): A társadalmi rétegződés komponensei, Budapest:Új Mandátum, 156-177.

Cvetkovic, N., Nikolic, D., Pavlovic, L., Djordjevic, N., Golubovic, M., Stamenkovic, S., \& Velikovic, M. (2014). The Socio Economic Status of Parents and Their Children's Sports Engagement, IN: Physical Education and Sport, 12, (2), 179-190.

Földesiné, Sz. Gy., Gál, A. \& Dóczi, T. (2010). Sportszociológia. Budapest: Semmelweis Egyetem Testnevelési és Sporttudományi Kar. 
Heim, R. \& Brettschneider, W. D. (2002). Sportliches Engagement und Selbstkonzeptentwicklung im Jugendalter, IN: Zeitschrift für Erziehungswissenschaft, 5, (1), 118-138. https://doi.org/10.1007/s11618-002-0007-9

Huszti, É. (2015a). Megismer-hetem - A személyes kapcsolathálózat új formája: kapcsolati napló. Debrecen: Debreceni Egyetemi Kiadó.

Huszti, É. (2015b): Mondd meg, kikkel töltöd az idődet, s megmondom, ki vagy. A társas támogatást nyújtó személyes kapcsolati háló néhány jellemzője és működése a Nyíregyházi járásban, IN: Acta Medicina et Sociologica, 6, 121-144. https://doi.org/10.19055/ams.2015.6/18-19/9

Pusztai, G. (2015). Tőkeelméletek az oktatáskutatásban. In Varga Aranka (Eds.): $A$ nevelésszociológia alapjai, Pécs: PTE BTK NTI Romológia és Nevelésszociológia Tanszék, Wlislocki Henrik Szakkollégium, 137-161.

Rácz, A. (2014). Egóközpontú kapcsolati hálók mérési módszerei, IN: Magyar Pszichológiai Szemle, 69, (3), 567-593.

Szokolszky, Á. (2004). Kutatómunka a pszichológiában. https://regi.tankonyvtar.hu/hu/tartalom/tamop425/2011 0001520 kutatomunka a p szichologiaban/index.html

Vastagh, Z \& Huszár, Á. (2008): Kapcsolatszegénység - Aki szegény az a legszegényebb? IN: Statisztikai Szemle, 86 (12), 1103-1125. 